\title{
Research on Comprehensive Reform of Secondary Colleges based on the Tertiary Management Mode of University, College and Department
}

\author{
Jianguo Luo ${ }^{1}$ \\ School of Mechanical and Electrical Engineering, North \\ China Institute of Science and Technology, 101601 \\ Beijing, China \\ luojg_1598@126.com
}

\author{
Jieqing Qiu ${ }^{2}$ \\ Graduate School, North China Institute of Science and \\ Technology, 10160 \\ Beijing, China \\ qiujieqinggood@163.com
}

\begin{abstract}
Colleges and universities implement the tertiary management mode of university, college and department, and universities give secondary colleges a large autonomy in teaching management. The reform of the management system is of great significance to improve teaching quality and educational benefit. The secondary college should deal with CDIO education and double base works well in the teaching and management services. In this case, comprehensive reform is carried out from the aspects of working mechanism, personnel, finance and teaching research.
\end{abstract}

Keywords-Secondary colleges; Management system; Comprehensive reform

\section{INTRODUCTION}

Colleges and universities implement the three-tier management model of university, colleges, and departments. Schools are the center of decision-making. Secondary colleges are the center of management. Departments (teaching rooms) and experimental centers are centers of quality. The administrative power of universities is gradually transferred to the secondary colleges. In order to better improve the efficiency of university management, the management of secondary colleges will face a more severe test. This article conducts an in-depth study on how to advance the comprehensive reform of the management system of secondary colleges and universities.

\section{THE BASIS OF THE REFORM OF THE SECONDARY COLLEGE MANAGEMENT SYSTEM}

The purpose of the reform of the secondary college management system is people-oriented, teaching is the center, scientific research is the key, management is the service, harmony is fundamental, and development is the goal. In order to promote the development of secondary colleges and universities, improve the quality of personnel training in colleges and universities. The reform of the secondary college management system follows the following principles.

\section{A. CDIO education model}

The three major social functions of colleges and universities in modern society are teaching, research, and social services. The university has become a training ground for highly qualified workers and builders. During the period of national economic transformation and industrial transformation and upgrading, some colleges and universities are also in the direction of applied universities.

The CDIO engineering education model is the latest achievement of the international engineering education reform in recent years. CDIO stands for Conceive, Design, Implementation, and Operate. Conduct heuristic, discussion, and inquiry teaching. Focus on enhancing students' practical abilities, nurturing the spirit of craftsmen, and providing students with mobile phone sessions to improve their ability to solve practical problems.

At present, college students should have professional knowledge, professional ability, social responsibility, innovation ability and engineering practice ability. Therefore, secondary colleges should provide protection in all aspects of teaching, and teachers should also have corresponding practical teaching ability.

\section{B. Education, management and service mode}

Combining the three major themes of education, management, and service facing the current student work, the student work in current colleges and universities should be based on a service-based teaching management model. Service-oriented education and management work must adhere to people-oriented. Establish service awareness and integrate ideological and political education management.

The starting point for student work is student-centered and taken students as the fundamental starting point and foothold for education. Establish the idea of putting equal emphasis on management and educating people, and combine institutionalized management with humanized management. Put the legitimate interests of students first. 


\section{C. "Double base project" construction}

"Dual-base project" construction refers to "grasping the grassroots and strengthening the foundation." The core is to do a good job in the construction of grassroots teaching organizations represented by departments, teaching and research rooms and experimental centers, strengthen the basic position of undergraduate education, improve the comprehensive ability of undergraduate personnel training, and strengthen the construction of undergraduate teaching conditions.

Through the form of joint meetings of the party and government, and all teacher conferences, the director of the department (teaching and research section, experimental center) and ordinary teachers must be able to participate in the decision-making and implementation of the major issues of the secondary college and lay a foundation for the effective development of the college's work. . It has achieved significant improvement in the sense of ownership, responsibility, and responsibilities of the department (teaching and research section), teachers in the process of education and teaching, and has achieved sustained and healthy development of the effect of education and teaching.

\section{CONTENTS OF SECONDARY COLLEGE MANAGEMENT SYSTEM REFORM}

By sorting out and summarizing the relevant provisions of the regulations of the Ministry of Education on the reform of education and teaching in institutions of higher learning, combined with the law of university education and the practice of universities, the reform of secondary college management is mainly carried out from the following aspects

\section{A. Reform of Secondary College Work Mechanism}

1) Decision mechanism: The secondary colleges implement the party-government joint conference system to study and decide important issues and major issues of the unit. The conference is convened and presided over by the dean or secretary according to different matters. The rules of procedure are implemented with reference to the "Responsibilities and Work Rules of the Party's Leading Cadres of the School".

2) Academic institution: The secondary college set up a sub-trade union organization to listen to the dean's work report (including the financial status report), discuss welfare matters for teaching staff, and safeguard the legitimate rights and interests of teaching staff. The secondary school party committee is responsible for the organization and development of the teachers and students of this unit. According to the authorization, the new party members are required to carry out the examination and approval of the new party members and prepare for the approval of the party members and report to the school party committee for filing. The college party committee may set up a part-time organizer as needed to take charge of the specific work of the organization's development.

3) Inter-school, international exchanges and cooperation: Strengthen inter-school and international academic exchanges and actively expand exchange channels. Teachers are encouraged to go abroad for study and participate in various academic conferences. Strengthen educational cooperation with universities at home and abroad to provide excellent opportunities for secondary students to study abroad.

Innovation and entrepreneurship education is different from traditional knowledge education. Its typical feature is actual combat. Therefore, in the curriculum setting, it is necessary to break the status quo of outdated teaching contents, single teaching methods, and the purpose of teaching to break away from the actual needs of enterprises. For this reason, it is necessary to collaborate with industry enterprises to innovate and jointly formulate a curriculum system with typical application characteristics [3].

\section{B. Reform of Secondary College Personnel Management System}

1) Staff appointment: The secondary college refers to the school's post setting plan and post appointment conditions, etc. and appoints the following personnel and reports to the school for the record: Lecturer and the following professional and technical positions, middle and below teaching assistant positions, below-level administrative posts, sanitation workers, teacher's concurrent dean (director of the teaching and research office), director of the institute, director of the experimental center.

2) Employment of external (including rerecruited) personnel: All kinds of external personnel are organized and inspected by the college and reported to the school for approval. If you need to hire part-time professors and guest professors because of your job needs, you will be hired by the secondary school and reported to the school for record (except for the letters of appointment from the school).

3) Work Arrangement and Assessment Management: Under the premise of guaranteeing completion of the school's planned teaching tasks, the secondary colleges can arrange teachers' teaching and scientific research tasks according to the school's teacher workload and assessment methods, organize teacher training, support the development of teachers, and continuously improve the overall quality of teachers and academic levels. The secondary college conducts day-to-day management of its staff and staff, and organizes assessments and rewards and punishments. 


\section{Reform of Secondary College Financial Management System}

1) Right to use funds: The secondary colleges use the funds allocated by the school to the college according to the national policies and the financial management system of the school. They include: Basic daily expenses, student activity funds, college students' science and technology innovation funds, undergraduate teaching project construction fees, teaching materials fees, teaching experiment materials and public consumables, student internship fees, academic activity funds, summer social practice fees, and school award scholarships, etc. The school allocates the performance allowance approval to the secondary college. The secondary school formulates the implementation rules according to the relevant regulations of the school, and assesses and issues them. The bonuses awarded by the superior department, relevant units and schools to the college are used by the secondary college for the development of the business and the rewards of teachers and students according to relevant regulations.

2) Financial Management Responsibilities: The dean of the secondary college is responsible for the implementation of the national financial regulations, policies and school financial management system in this department, shall earnestly perform the "one pen" examination and approval responsibilities for funds within the scope of economic management according to law, shall prevent problems such as violating regulations, discipline, loss and waste, should ensure that all financial revenue and expenditure activities are included in the school's annual budget and strictly implement the "two lines of revenue and expenditure". Execute school budget approval, allocate funds rationally and legally, and strictly implement the standards and scope of expenditure; all expenditures shall obtain legal original vouchers, and false reports shall not be made; false prohibition shall be imposed on unauthorized collection of funds, or collection, misappropriation, misappropriation of school income, etc., Put an end to the phenomenon of "little treasury"; the creditor's rights and debts of this unit are clear.

3) Other Matters: The school implements a unified financial management system with unified leadership, centralized accounting, and hierarchical management. The secondary college establishes a security ledger, does not set up a separate financial institution, does not perform accounting separately, does not open a bank account, and is accounted for by the Finance Department on a unified basis. The college sets up financial contact personnel according to job requirements. The expenditure of the dean of the secondary college is examined and approved by the school's leader in contact with the college. The audit office audits and supervises the financial income and expenditures and economic activities of the secondary colleges, and conducts economic responsibility audits for the president of the college in accordance with regulations.

\section{Reform of Secondary College Financial Management System}

1) Professional Construction: The secondary college developed the professional construction plan of the college, independently adjust the direction of the profession within the scope permitted by the national policy and the school regulations, and propose the adjustment of the professional enrollment scale according to the professional enrollment and employment situation, they are responsible for the preliminary advice and argumentation of the new professional establishment, responsible for professional laboratory construction and management. Actively carry out teaching reform and other teaching quality construction activities.

2) Teaching operation and management: Secondary colleges develop training programs and teaching plans, and is responsible for the execution and management of teaching plans, teaching quality monitoring, curriculum construction, teaching materials construction, graduation thesis (design) and thesis defense, student exchanges, teacher arrangement and adjustment, teaching assessment and workload calculation, etc.

3) Teaching quality guarantee and evaluation: The secondary college establishes the "two-level supervision and three-level prevention" mechanism for teaching quality, the "secondary supervision" means the supervision of the department room, the supervision of the college, and"threelevel prevention" means teachers' self-examination and prevention errors, cross-checks and errors in the departmental room, and the college supervisory team checks for errors. Let teachers, department (teaching and researching rooms) directors, secondary supervisors, and colleges perform their duties in the process of preparation and review of teaching work to minimize defects and deficiencies and effectively improve the standardization of teaching.

\section{E. Reform of Secondary College Scientific Research Management System}

Based on the school's science and technology development plan, the secondary college condenses its research direction, builds an innovative team, and organizes its teachers to carry out scientific research and production, research, and research work, responsible for reviewing the materials submitted by the Institute for scientific research projects and conducting feasibility assessment and risk assessment, responsible for the construction of scientific research bases, scientific research and development, transformation of achievements, organization and management of social services, academic exchanges, scientific research achievements, and preliminary examination of projects. The second-level college is also responsible for the selection and appointment of academic leaders and academic leaders in this school and reports to the school for record. Collect, count, and manage information on the science and technology work of this hospital. 
Through the establishment and improvement of scientific research management systems, adjustments, and the introduction of corresponding scientific research incentive policies, we have fully mobilized the faculty's enthusiasm for scientific research and initiative; consolidated and adjusted key research directions, strengthened research team building, and improved scientific research and innovation capabilities.

\section{CONCLUSION}

The reform of the secondary college management system has made the education of the general higher education institutions more focused on basic education and engineering practice. It has also proceeded from the legitimate rights and interests of students and is more conducive to the development of scientific research in colleges and universities. Therefore, the reforms make ordinary college education more adapted to the current economic development needs of the country and are more conducive to improving the quality of personnel training in universities and better serving society.

\section{ACKNOWLEDGMENT}

This work was financially supported by NCIST High Education Research Fundation (HKJYGH201604), and HeBei Province Education Reformation Foundation (2015GJJG254), and HeBei Province Education Association Fundation (GJXHZ2017-06).

\section{REFERENCES}

[1] Liu Yu. Research on the management mode innovation of two level colleges in local universities [D]. Hunan: Xiangtan University, 2010. (In Chinese)

[2] Chen Jie. Several discussions on strengthening the style of study under the service oriented education management mode $[\mathrm{J}]$. higher vocational education research, 2011, (12):181-182. (In Chinese)

[3] Wang Yan, Huang Tao. Reform of two level teaching management system in Colleges and universities [J]. Heilongjiang education [J], 2013 (7): 3-4. (In Chinese)

[4] Hong Hong. Research on the reform of teaching management in two level colleges and universities in China $[\mathrm{J}]$. China Electric Power Education: 2013, (25): 62-64. 